\title{
Paradox of Sport and Politics in China - Applied to C.L.R. James' Theory
}

\author{
Chenxi Pan \\ Department of Basic Training, Zhenjiang Watercraft College of PLA \\ 130 Tao Hua Wu Road, Zhenjiang 212003, China \\ E-mail: panchenxi@yahoo.cn
}

Received: July 28, $2011 \quad$ Accepted: August 18, $2011 \quad$ Published: December 1, 2011

doi:10.5539/ass.v7n12p222 URL: http://dx.doi.org/10.5539/ass.v7n12p222

\begin{abstract}
According to C.L.R. James's social theory on cricket and social movement, a paradox between sport and politics is presented. Sport used to contribute to, as well as ruin the politics. In China, Sport has been played a significant role for developing in many aspects, including politics. In this paper, the complex relationship between sport and politics is analysed and discussed from a historical perspective. In order to keep on constructing the positive impact from sport and politics, the position of both should be paid attention to. Meanwhile, it should be realised that sport is not the representatives of politics. Sport and politics influence each other rather than unrelated or absolute dependence relation.
\end{abstract}

Keywords: Sport, Politics, Paradox, C.L.R. James, China

\section{Introduction}

Sport is an important part of social activities of human life. The formation and development of sport is related to some certain history backgrounds. At the same time, sport played an irreplaceable role to the society. There is an interaction between sport and social. During the process of social developing, sport impacts the social by its particular way. It acts on politics, economy, culture and education, and as one of the level for the developing of human society. As a unique phenomenon of human society, it related to its social superstructure of its era. The main point of this article is the relation between sport and one of the aspects of society, politics. Politics determines the character of sport, and on the other hand, sport serves politics. Since the variety of social system from country to country, it is nature that the politics of each country are different. Although the basic relation between sport and social is quite similar of the whole world, no matter what kind of social system the country implements, there must be some particular features. An objective and comprehensive understanding of the relationship between the two concepts, is helpful to keep a balanced developing of both. Therefore, the advantages are supposed to be promoted, while the disadvantages need to be avoided. In other words, sport can step up the social progress, and be developed faster because of the adaptation to local circumstances.

\section{Social Theory Applied to from C.L.R. James}

C.L.R. James was born in Trinidad in 1901 and died in London in 1989. He was fundamentally a political person holding a unique standpoint on life, art, sport and politics according to his witness of a myriad of events during an intellectually rich life. He is most widely known as a writer on cricket, especially for his autobiographical 1963 book, Beyond a Boundary and his views were formed by his own experiences or observation. The book showed the importance of cricket in his culture and civilisation from socialize and politics aspects.

Cricket's political resonance, as the book's title suggests, extends beyond the "boundary" of the cricket pitch and, moreover, interrogates the tenuous boundaries that separate culture from politics, race from class, and high culture from low. As James argues in the preface, "It [the book] poses the question 'What do they know of cricket who only cricket know?"' Deeply implicated in the workings of intra- and international politics, Cricket is fundamentally unthinkable outside of the context of British colonial rule -- much in the same way that West Indian colonialism and decolonization are unthinkable without cricket.

James gave us an excellent beginning point for an analysis of why sports politics have been so important at two levels: the domestic, and the global. And he was among the first to recognize the inextricable link between sport 
and politics, and the sophistication of his analysis remains. James' analysis provides a good way into a paradox, that cricket is a reflection and a manifestation of a particular 'world' that uses the game to help survive wider sweeping social change. Applied James' theory to the general relationship of sport and politics, the paradox still exists. For example, in Australia and New Zealand, where the Anglo code prevailed, the idea of separating sport from politics was strong while in West Indies the connection between sports form and social structure was more intimately.

\section{Relation between Sport and Politics}

\subsection{Basic meaning of Sport and Politics}

As the fast development of science and technologies, and the consistent increase of human's living standard, sport spread from schools to the society, and become one of the most important parts of people's ordinary life. And the impact from sport is much more beyond the range of schools. According to Max's theory about country, politics is the product of class society, is the performance of economy. And Lenin thought politics is the struggle between different sections. Therefore, politics is not only a conception of class, but also a category of history. It is determined by economy basis, and bears the sign of the times.

In China, sport and physical education is the same word, so called 'Ti Yu'. It used to only mean a kind of education to body activities. However, up to $1950 \mathrm{~s}$, it is found that the traditional meaning of sport could not include all the aspects of it any more. Sport has more connotations than before. Beside physical education, there are competitive sports, body building, and even entertainment activities, which are different but still related to others. Therefore, sport is developing to a new system that with close connection to politics, economy and so on.

\subsection{The Paradox}

In any kind of society, politics is always comes the first. So when discussing or analysing of relation between sport and society, first has to be mentioned is politics. For a long time, there have been voices discussing about the paradox as following: Should sport be separated from politics? Yes. Could sport be separated from politics? No. To some researcher's mind, although sport cannot get out of the control of politics, it doesn't mean that it is reasonable.

Some professionals insist the original spirit of sport and prefer sport not to be used as a tool of politics. Avery Brundage, former president of International Olympic Committee, had been aimed to "separate sport from politics". In China for example, people hold a brief for pure sport argue about the result of sport competitions. They put up a question: if a win of competition can be seen as a glorious honour, what would lose stand for? It is emphasised that sport should beyond the limit of country and get out of the control of politics.

It is true that a clean and pure environment is good for the development of sport. However, the human beings won't waste the use value of sport for politics, at least at the present stage. Accordingly, the paradox between sport and politics could not be settled in a short term of time. The idea of separating sport out of politics at the present period is quite like an unrealistic Utopia.

\subsection{The Historical Link between Sport and Politics}

Sport, as a socio-cultural phenomenon, is always developing accompanied by the progress of social economy and cultural. Sport contains not only political purposes, but also political means in nature. The close connection between sports and politics is not only appeared in modern society, but also in the remote past. The political function of sport, nevertheless, was not understood and utilised by human beings until the human society developed.

As Engels emphasized in the essay "The part played by labor in the transition from ape to human", humanity was created by labor. Sport, as a part of social culture, also stemmed from labor. In primitive society, the main social activities are searching for food, attacking and defending. Primitive man had to run fast in order to hunt small animals, use simple weapons with throwing power in order to defend large animals, master swim in order to fishing. When primitive man realized the importance of these skills and capabilities, and then did exercises actively, sport appeared.

Although the appearance of sport was from labour, the development of sport was intimately related to war. Original wars appeared at the later period of gentile community. Wars propelled the development of weapons and fighting skills. Sport was important in training physical fitness and body development. In order to survive and defence the invasion of other groups, ancient warriors had to have the advantage of stronger physique. At that time, sport was closely related to war. That is to say, military was an important driving force for developing sport. Meanwhile, sport severed the military, the survival, and also the politics. Therefore, sport was always used as 
tool in class conflict from the very beginning. Along with the improvement of production capability, sport is gradually separated from the original purpose and became a significant role of education. Each country made their special traditional sport, such as martial arts in China, and sepak takraw in Southeast Asia. The type of traditional sports was deepened on local politics, culture and level of science technology. Sport supported the rule of governing class and played a role of talents selection.

Olympic movement has being growing up since the end of 19th century. From then on, sport has gone beyond the category of education. As the great development of international economy, people have taken sport as a quite vital part of daily life progressively. To attend in sport activities, has becoming a social trend. People spontaneously take part in various active sports, leisure sport and holiday sports for instance. The remarkable headway of sport reflects the advancement of social, not only the economic prosperity, but also the democratization of politics. From a historical and rational perspective, it is not difficult to testify the close link between sport and politics.

\subsection{Politics Influence on Sport}

Politics system determines who sport serves to. According to Marxian way of thinking the proletariat will always lose to the aristocrat in the practice of sport until there is a workers' revolution. In ancient China, sport was as a sign of class. Only the ruling class has the right to enjoy sports. But Antonio Gramsci stated that the ruling class making important compromises with the working class. On the other hand, sport as a social activity and cultural, it also has the side not related to politics that much. It can enrich people's life and build body up.

In each nation, there are different groups seeking for diverse interests. However, the nation interests always occupy the centre-stage. The Olympic Games for example, for the purpose of denouncing Soviet Union's invasion of Afghanistan, in the year 1980, many countries refused to attend the Moscow Olympic Games, although the IOC insisted that Olympics should be apart from politics. As an athlete, to attend the Olympic Games is of great significance for he or she has to prepare for the competition for at least four years. For ordinary people, the athletic career cannot stand too long. Nevertheless, in any kind of situation, the national interests possess the top priority all the time.

The development of sport cannot be isolated from economic foundation. With the purpose of using sport as a political tool, the national investment for sport of each nation is growing year by year. The economic project would benefit the sport by means of building high quality stadiums, fixing corresponding sport facilities and soon. Media, as the mouthpiece of national ruling class, is used for publicising and encouraging citizens to attending sport activities. It helps to enhance their physical constitution and promote national political stability.

Now communist China is at the primary stage socialism, sport plays a role of insisting the basic policy of Communist Party, serving for all people and making contribution to the socialist construction, especially in promoting cultural and ideological progress. Although there may be some problems make it difficult to really reach 'all people' at the moment, but it is a goal and a kind of ideology. In 1998 there was a reform of government organization in China, and it also leaded to the reform of sport system. 'The State Physical Culture and Sports Commission' was reorganized into 'General Administration of Sport of China'. It changed from a public institution into a administrative district. It showed that the management of sport is changing followed the politics.

The relationship between sport and politics in China from 1949 to 1999 has been profound. Sport has assisted the acceptance, implementation and endorsement of ideology. It has enabled China to make approaches to Western opponents through a medium with a non-political image, as for example, in the well-known moment of 'ping-pong diplomacy'. Sport has also been used to strengthen relations between socialist allies. The famous slogan 'Friendship first; competition second' served a useful purpose. It provided China with allies, supporters and admirers at a time of vulnerable transition. Sport deserves credit for assisting New China to transform, consolidate and advance her political ideas and diplomatic image on the world stage.

\subsection{Sport Serves Politics}

In the nature of uncertain result, sport competitions attract people's attention on the outcome. Most international games are joined by the units of countries, so sometimes the performance of athletes is under a kind of political means. Victory or defeat, is not only related to the athletes, but also to the nation they representative. Once we won, it would bring pride to the whole nation. In other words, national spirit is the direct connection between sport and politics. On the other hand, inside the country, according to the fact that China is a country with fifty-six ethnic groups, sports competitions at different levels are helpful for each group to understand one another and strengthen friendship between them. 
Sport is helpful in developing the society. The level of sport could reflect the economy basic and social system in some degree. In old China, according to the corruption and incapable of old authority government, the sport in China was far behind other countries of the world, and there were not enough labour power or financial resources to join big international games. As a result of that situation, China used to be called 'sick man in east Asia'. However, after the foundation of New China, especially after the reform and opening-up in 1978, sport has developed fast. Recent years, sport industry has been growing fast and steadily. In the year 2008, China held the 2008 Olympic Games in Beijing. From the win of bidding 2008 Olympic Games to China joined the WTO, till the successful holding of the great sport event, China showed noticeable improvement on economy and politics to the world. Meanwhile, the 2008 Beijing Olympic Games made a great effect to the politics of China. The international status was enhanced; national identity was strengthened; social cohesion and integration were heightened; general mood of society and administrative capacity of government was improved; the whole social development was speeded up.

Most countries utilise sport for diplomacy. Sport is used as a tool to improve relationship between different countries, as well as against some kind of political forces. Since the form of sport is non-political, any country with different ideologies can take part in the game. In international sport events, the friendship among athletes from different countries is built in the field. Accordingly, in certain circumstances, sport event is held as a moment in order to break the diplomatic deadlock. A famous case of China is the 'ping-pong diplomacy' which always been talked about. In 1971, the ping-pong visiting between China and the USA broke the deadlock which had last for more than ten years of two countries. And this event was described as 'small ball turned the big ball (the Earth)' by politicians. The next year, Richard Milhous Nixon, former U.S. President, visited China officially. From then on, a bridge across the river, which was sixteen thousand miles with hostility for 22 years, was finally built.

\section{Conclusion}

Sport is multi-functional, including the political function. Although the function related to politics is important, it cannot replace others. The development of sport is conditioned by politics. But not all the sport problems are related to politics.

As a special culture phenomenon, sport influence on politics internal and international obviously. Contemporary society is politicised. The sport politicised is unavoidable to some extent. It is not reality or scientific to cut off the link between sport and politics. However, it is should be noticed that although sport and politics are inseparable, they are different, which means sport is not equal to politics. Sport serves politics, but also develops in its own track. It is not encouraged to overemphasize the abuse of the political function. In the meantime, sports politicised should be played down.

Juan Antonio Samaranch, former president of the International Olympic Committee, indicated that keeping sports out of politics was not an easy task. "It is very easy to say that sports has nothing to do with politics, but you can find politics everywhere" and "This problem is solved bit by bit, step by step, I am sure it will be solved".

The relationship between sport and politics changes according to the periods of history and social background that used to research on. In ongoing economic globalization, win-win relationship is necessary for overall social progress and harmonious social development.

\section{References}

Beckles, H. M., \& Stoddart, B. (1995). Liberation Cricket: West Indies Cricket (Sport, Society, and Politics). Manchester: Manchester University Press, pp. 256-259.

Engels, F. (1975). The part played by labour in the transition from ape to man. Beijing: Foreign Languages Press.

Gruneau, R. (1999). Class, Sports, and Social Development. Champaign: Human Kinetics, pp.99-103.

Liu, H.T. (2004). Mutual functioning research on the relationship between physical education and politics. Journal of Liaoning Technical University (Social Science Edition), 6(4): 437-439.

Tian Y.P. (2001). The Politic Function of Sports in New Era. Journal of Tianjin Institute of Physical Education. 16(1): 7-8. 